ORIGINAL RESEARCH ARTICLE

\title{
Assessment of physico-chemical and heavy metals properties of some agricultural soils of Awing-North West Cameroon
}

\author{
Nelson Alakeh Mofor ${ }^{2}$, Estella Buleng Njoyim Tamungang ${ }^{1,2 *}$, Antoine David Mvondo-zé3, Georges \\ Kogge Kome ${ }^{3}$ and Kenneth Mbene ${ }^{4}$
}

${ }^{1}$ Department of Chemistry, Higher Teacher Training College, The University of Bamenda, Bambili, CAMEROON

${ }^{2}$ Laboratory of Noxious Chemistry and Environmental Engineering, Department of Chemistry, Faculty of Science, University of Dschang, Dschang, CAMEROON

${ }^{3}$ Laboratory of Soil Analysis and Environmental Chemistry, Department of Soil Science, Faculty of Agronomy and Agricultural Sciences, University of Dschang, Dschang, CAMEROON

${ }^{4}$ Department of Chemistry, Higher Teacher Training College, University of Yaounde 1, P.O. Box 47, Yaounde, CAMEROON

*Corresponding author's E-mail: bulengyim@yahoo.com

\section{ARTICLE HISTORY}

Received: 09 November 2017

Revised received: 18 November 2017

Accepted: 25 November 2017

\section{Keywords}

Immobilization

Liming

Mobilization

Soil $\mathrm{pH}$

Soil quality

\begin{abstract}
This research work was aimed to assess the quality of agricultural soils of Awing-North West Cameroon by elucidating some physicochemical properties and heavy metals in the soils. Agricultural yields in Awing have witnessed a decline in recent years and farmers have repeatedly used fertilizers to improve on their agricultural yields. It is thus important to test the soil in order to ensure not only high productivity but its quality as well and suggest methods to increase agricultural yields, while preventing soil and water pollution. Twenty soil samples were randomly collected from four sites, Achialum, Meupi, Nepele and Ala'amiti, in Awing and analysed for physicochemical and heavy metal properties using standard methods. Results showed that all the soils had low bulk densities (0.76-0.89 $\left.\mathrm{g} \mathrm{cm}^{-3}\right)$, low $\mathrm{pH}$ values (4.1-6.0), low electrical conductivities $\left(0.02-0.11 \mathrm{mS} \mathrm{cm}^{-1}\right)$, low available phosphorus (1.55-14.26 mg kg-1) and the soil textural class was dominated by loam. The mean available concentrations of heavy metals ranged from 0.24-2.73, 0.64-5.13, 13.79-34.51, 29.4592.27, 0.00-0.80, 0.24-4.54, 0.68-1.39, 0.30-0.47 $\mathrm{mg} \mathrm{kg}^{-1}$ for $\mathrm{Zn}, \mathrm{Cu}, \mathrm{Mn}, \mathrm{Fe}, \mathrm{Pb}, \mathrm{Ni}, \mathrm{Cr}$ and $\mathrm{Cd}$ respectively. Results of heavy metal analysis showed that the soils were contaminated to different levels (above FAO/WHO limits) by the different heavy metals. Natural origins, fertilizer application and domestic waste were identified as the major sources of heavy metals in the soils. Future research should focus on the development of methods to quantify lime-enhanced mobilization of nutrient ions and lime-induced immobilization of heavy metals in these soils.
\end{abstract}

(C)2017 Agriculture and Environmental Science Academy

Citation of this article: Mofor, N.A., Tamungang, E.B.N., Mvondo-zé, A.D., Kome, G.K. and Mbene, K. (2017). Assessment of physico-chemical and heavy metals properties of some agricultural soils of Awing-North West Cameroon. Archives of Agriculture and Environmental Science, 2(4): 277-286, DOI: 10.26832/24566632.2017.020405

\section{INTRODUCTION}

The yield of agricultural production is highly determined by soil quality. Plants, just like other living beings, need food for their growth, development and reproduction (Njoyim et al., 2016a). The challenge for agriculture in the world today is to meet the world's increasing demand for food in a sustainable way and declining soil fertility and mismanagement of plant nutrients have made this task more difficult (Yerima and Van Ranst, 2005; Yaser and Rahim, 2013). A soil is known to be rich for agriculture depending on its nutrient content, amongst other physico-chemical factors such as soil $\mathrm{pH}$. Thus, assessing the quality of soils (nutrient content) used for agricultural production is paramount for the maintenance of optimum growth conditions needed by plants for maximum yields (Njoyim et al., 2016a).

Soil degradation is widely recognized as major agricultural and environmental problem (Ruqia et al., 2015; Njoyim et al., 2016b). There is tremendous need for greater understanding of Cameroonian soils, and to develop management options to help increase agricultural productivity while nurturing soil health and preventing water pollution. The problem of farmland contamination by heavy metals has raised serious concerns for emerging countries such as Cameroon (Njoyim et al., 2016c). Soil chemistry distinguishes heavy metals as a special group of elements because of their toxic effect exerted on plants upon their high concentrations (Vodyanitskii, 2016). Depletion of plant nutrients in the soil is a major problem in the Awing community where most of the inhabitants depend so much on agricultural production for their livelihood. Human induced processes such as industrial establishment, mining, agriculture and transportation, release high amounts of heavy metals into soils, surface and ground water and 
ultimately to the biosphere (Oluyemi et al., 2008; Ruqia et al., 2015). Heavy metals pollution in agricultural soils has become one of the global challenges facing food production and the sustainability of life. It has been reported that pollution of agricultural soils can be as a result of long-term farming or excessive use of agrochemicals (Osobamiro and Adewuyi, 2015). The contaminants accumulated in the plants not only affect the growth and quality of crops but also threaten the health of consumers (Cheng and Huang, 2006). The most common heavy metal contaminants are $\mathrm{Cd}, \mathrm{As}, \mathrm{Cr}, \mathrm{Cu}, \mathrm{Hg}$, $\mathrm{Pb}, \mathrm{Ni}$, and $\mathrm{Zn}$. Some of these metals such as $\mathrm{Zn}, \mathrm{Cu}, \mathrm{Mn}, \mathrm{Ni}$, and $\mathrm{Co}$ are micronutrients necessary for plant growth, while others such as $\mathrm{Cd}, \mathrm{Pb}, \mathrm{As}$, and $\mathrm{Hg}$ have no known biological functions and are very toxic to human health. There are various sources of heavy metals; some originates from anthropogenic activities like draining of sewerage, dumping of hospital wastes and recreational activities. Conversely, metals also occur in small amounts naturally and may enter into aquatic system through leaching of rocks, airborne dust, forest fires and vegetation (Oluyemi et al., 2008; Ruqia et al., 2015). Plants grown on land polluted with municipal, domestic or industrial wastes can absorb heavy metals in the form of mobile ions present in the soil solution through their roots. These absorbed metals get bio-accumulated in the roots, stems, fruits, grains and leaves of plants (Oluyemi et al., 2008).

Agriculture is the backbone of the economy of Cameroon. The Awing community is highly dependent on agriculture for its growth and development and thus it is necessary to evaluate soils used for crop production in this community and suggest methods to improve on agricultural yields, while preventing water pollution in all its forms. Literature shows that no previous works have been carried out to evaluate the potentials of these soils for agricultural production. For soil to produce crops successfully, it must not just have an adequate supply of all necessary nutrients that plants need, but must also be totally free from toxic heavy metals. Due to the fact that most farmers in in Cameroon and Awing in particular use fertilizers (which are sources of heavy metals) to improve on their agricultural yields; it is therefore important to test the soil in order to ensure not only high productivity but its quality as well (Njoyim et al., 2016c).

Confronted with the above problem, the major objective of this research work was to evaluate the quality of some agricultural soils in Awing in order to provide information on the nutrient status and the level of heavy metal contamination of the soils. To achieve this objective, physico-chemical and heavy metal properties of the soils were determined and correlated to one another. Recommendations were then made from the findings of the research and methods suggested to increase agricultural yields, while preventing soil and water pollution.

\section{MATERIALS AND METHODS}

Site descriptions: Awing is found in the grass field zone of Cameroon; precisely in Santa Sub-division of the North West region of Cameroon (Figure 1). It is situated at about $21 \mathrm{~km}$ south-east of Bamenda. Awing has a surface area of about 480 $\mathrm{km}^{2}$ and as of the year 2010 , its population density stood at 115.2 people $/ \mathrm{km}^{2}$. Located between latitudes $05^{\circ} 47^{\prime}$ to $06^{\circ} 00^{\prime}$ $\mathrm{N}$ and longitudes $10^{\circ} 10^{\prime}$ to $10^{0} 22^{\prime} \mathrm{E}$, Awing has an elevation of about $1206 \mathrm{~m}$ above sea level. Its topography is troughlike, a low lying plain, surrounded by an extension of the volcanic chain of the Bambouto Mountain in the West, North and East; hemmed by a network of hills. The highest point is Mount Lefo (fourth highest mountain in Cameroon); with a height of $2550 \mathrm{~m}$ on whose northern flank is Lake
Awing (NACDA, 2010; Apongnde, 2014). Prominent in Awing are cone-shaped hills which are covered by savannah, shrubs and montane forest; with volcanic rocks underneath. Most of these high lands serve as pasture and arable fields. Awing is drained by two main streams which collect their waters from the tributaries of the surrounding hills and mountains. In the West is the 'nkiachialu' (Achialum stream) while in the East is the 'nkindzom' (Mbenjom stream). Besides, these two main streams are a number of seasonal streams and springs which all meander southwards to meet in the Nepele neighbourhood from where they empty themselves into the River Noun in the West region of Cameroon. Awing falls within the mountainous areas of the Bamenda highlands with a sub-equatorial climate. The latter is characterized by two main seasons: the rainy and dry seasons. The rainy season runs from mid-March to about late October; with an annual rainfall ranging from about $240.98-260.65 \mathrm{~mm}$ between 1995 and 2010, according to Trials and Demonstrations Center (T.D.C) Santa. It is often characterized by heavy rains and average temperatures whose average since 1996 has been above $19{ }^{\circ} \mathrm{C}$. The dry season runs from late October to about mid-March. It is accompanied by dry harmattan winds and fluctuations in temperatures. Temperatures sometimes rise up to about $35{ }^{\circ} \mathrm{C}$ during the day and drop to about $16{ }^{\circ} \mathrm{C}$ at night. On the whole, Awing is predominantly cold round the year (Apongnde, 2014).

Site characteristics, field methods and sampling: Sampling was done in December 2016. Four representative sites were selected, based on their agricultural potentials. The sites are: Achialum (AC), Meupi (ME), Nepele (NE) and Ala'amiti (AL). In each site, five composite surface soil $(0-20 \mathrm{~cm})$ samples were collected randomly using a soil auger. Undisturbed core samples were also collected with a $100 \mathrm{~cm}^{3}$ Kopecky ring for bulk density determination. All samples were stored in polythene bags. Achialum is located on Longitude $10^{\circ} 13^{\prime} 56^{\prime \prime} \mathrm{E}$, Latitude $05^{0} 50^{\prime} 39^{\prime \prime} \mathrm{N}$, with an elevation of $1627 \mathrm{~m}$ above sea level. It is about $200 \mathrm{~m}$ from G.S Nkonbeng and about $30 \mathrm{~m}$ from Achialum spring. It has a slope of $15-20 \%$. The parent material is rhyolite and the vegetation is grass land type mixed with patches of raffia and plantains. The drainage is very good and the land use is mixed cropping (Maize, beans, cocoa yams) for more than 10 years. The soil colour is 5YR 3/4 (Dark reddish brown) in the dry state.

Meupi is located on Longitude $10^{\circ} 14^{\prime} 24.2^{\prime \prime} \mathrm{E}$, Latitude $05^{0} 50^{\prime}$ $13.9^{\prime \prime} \mathrm{N}$, with an elevation of $1589 \mathrm{~m}$ above sea level. It is about $30 \mathrm{~m}$ from Meupi spring, $1 \mathrm{~km}$ from CBC Mbejah and situated at the foot of mount Lefo. It has a slope of $0-2 \%$. The parent material is rhyolite and the vegetation is grass land type mixed with patches of raffia and coffee. The drainage is good and the land use is mixed cropping (Maize, beans, cocoa yams, coffee) for more than 20 years. The soil colour is 7.5YR 6/4 (Light brown) in the dry state.

Nepele is located on Longitude $10^{0} 16^{\prime} 24.8^{\prime \prime} \mathrm{E}$, Latitude $05^{0} 48^{\prime}$ $08.3^{\prime \prime} \mathrm{N}$, with an elevation of $1332 \mathrm{~m}$ above sea level. It is about $1 \mathrm{~km}$ from G.H.S Awing along the Nepele- Three Corners road. It has a slope of $0-2 \%$ and the climate is tropical grassland type. The parent material is trachites and the vegetation is characterised by the presence of Chromolena odorata, spear glass (Hypalena) and mixed grass land type. The drainage is good and the land use is mixed cropping (Maize, beans, sweet potatoes, cassava) for more than 20 years. The soil colour was 5YR 4/3 (Reddish brown) in the dry state. Ala'amiti is located on Longitude $10^{0} 14^{\prime} 35.8^{\prime \prime} \mathrm{E}$, Latitude $05^{\circ} 52^{\prime} 37.8^{\prime \prime} \mathrm{N}$, with an elevation of $1756 \mathrm{~m}$ above sea level. It is about $100 \mathrm{~m}$ from Ala'amiti spring and about 
$100 \mathrm{~m}$ from Ala'amiti square. It has a slope of $8-10 \%$ and the climate is tropical grassland type. The parent material is basalt and the vegetation was grass land type. The drainage is good and the land use is mixed cropping (maize, beans, cassava, cocoa yams) for more than 20 years. The soil colour is $5 \mathrm{YR}$ $4 / 3$ (Reddish brown) in the dry state.

Laboratory analysis: Fresh soil samples from the field were air dried in the laboratory, ground in a porcelain mortar using a pestle and sieved through a $2 \mathrm{~mm}$ sieve. The fine earth $(<2$ $\mathrm{mm}$ ) was then analysed for the various physico-chemical and heavy metal properties using international standard methods (Benton, 2003). All chemicals used in these analyses were of analytical grade. The bulk density of the soils was determined over a soil volume of $100 \mathrm{~cm}^{3}$. Bulk density is the oven dry $\left(105{ }^{\circ} \mathrm{C}\right)$ weight of soil per unit volume. It is expressed in $\mathrm{g}$ $\mathrm{cm}^{-3}$ and was calculated using the following equation:

Bulk density $=\frac{\text { Mass of oven dry soil }}{\text { Volume of soil core }\left(100 \mathrm{~cm}^{3}\right)}$

Soil $\mathrm{pH}$ was measured in a 1:2.5 soil-solution ratio in $1 \mathrm{~N} \mathrm{KCl}$ $(\mathrm{pH}-\mathrm{KCl})$ and distilled water $\left(\mathrm{pH}-\mathrm{H}_{2} \mathrm{O}\right)$. Exchangeable acidity $\left(\mathrm{H}^{+}\right.$and $\left.\mathrm{Al}^{3+}\right)$ was determined by titration with $\mathrm{NaOH}$ after extraction with $1 \mathrm{~N} \mathrm{KCl}$ in a soil-solution ratio of 1:20. Electrical Conductivity (EC) was determined after extraction with distilled water in the ratio 1:5 with a conductivity meter (WTW model). Exchangeable bases were determined by the method of Schollenberger by percolating $2.5 \mathrm{~g}$ of soil with $100 \mathrm{~mL}$ of $1 \mathrm{~N}$ ammonium acetate, after which sodium and potassium ions were determined by flame photometry while calcium and magnesium ions were estimated by complex metric titration. Cation Exchange Capacity (CEC) was estimated by percolating $2.5 \mathrm{~g}$ of soil with $100 \mathrm{~mL}$ of $1 \mathrm{~N}$ ammonium acetate and then with $1 \mathrm{~N} \mathrm{KCl}$, the collected $\mathrm{NH}_{4}{ }^{+}$ions were then determined by distillation and titration with a $0.01 \mathrm{~N}$ sulphuric acid. Total nitrogen was estimated by exploiting the Kjeldahl's distillation method while Soil Organic Carbon (SOC) was estimated by oxidation with potassium dichromate and titration with iron (II) sulphate. Particle size distribution was determined by the hydrometer method. Available phosphorus was determined by Bray II method. The levels of heavy metals were determined using Atomic Absorption Spectrometry (AAS) analysis. Available elemental concentrations were determined using Melich 3 extraction solution while total elemental concentrations were done using aqua regia (a mixture of conc. $\mathrm{HNO}_{3}$ and $\mathrm{HCl}$ in the volume ratio of 1:3) extraction solution.

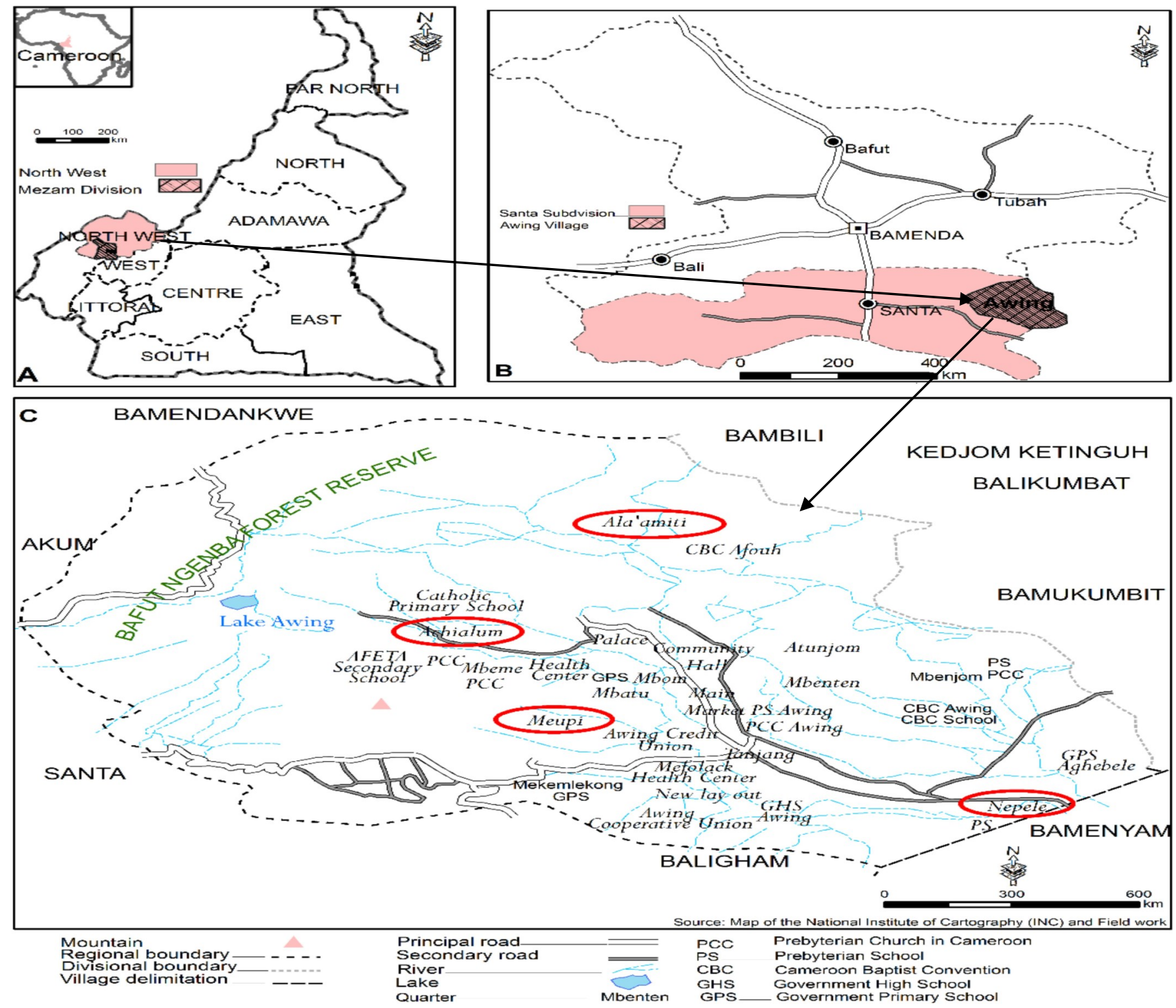

Figure 1. Map of study area: $A=$ Map of Cameroon showing North West and Mezam Division, $B=$ Map of Mezam Division showing Awing, $C=$ Map of Awing showing sampling sites. 


\section{RESULTS AND DISCUSSION}

Results of physico-chemical analyses for Achialum (AC), Meupi (ME), Nepele (NE) and Ala'amiti (AL) samples are presented in Table 1. Results showed that the soils had low bulk density values ranging from 0.76 to $0.89 \mathrm{~g} \mathrm{~cm}^{-3}$ with mean values of $0.77,0.88,0.77$ and $0.85 \mathrm{~g} \mathrm{~cm}^{-3}$ for Achialum, Meupi, Nepele and Ala'amiti sites respectively. The low bulk density values for the soils could be the result of a combination of the amorphous volcanic material and organic matter, which results in light fluffy soils that are easily tilled, and have a low water-holding capacity (Yerima and Van Ranst, 2005). Tematio et al. (2004) and Njoyim et al. (2016b) had similar values of bulk density $\left(0.53\right.$ to $\left.0.90 \mathrm{~g} \mathrm{~cm}^{-3}\right)$ on the soils of mount Bambouto. All the four sites were slightly to very acidic with $\mathrm{pH}$ values ranging from $4.10-6.0$ with mean values of 5.66, 4.32, 5.52 and 5.46 for Achialum, Meupi, Nepele and Ala'amiti sites respectively. When the soil is acidic, the availability of nitrogen, phosphorus, and potassium is reduced (Silva and Uchida, 2002). This is probably because at low $\mathrm{pH}$ values, oxides and hydroxides of iron and aluminium become soluble and tends to fix these nutrients (Njoyim et al., $2016 \mathrm{~b}$ ). Soil $\mathrm{pH}$ can be increased by liming (the application of calcium carbonate or calcium hydroxide). Liming has often been shown to enhance the mineralization of organic matter, thereby releasing inorganic plant nutrients such as $\mathrm{N}, \mathrm{S}$ and $\mathrm{P}$ to soil solution. Unless these nutrients are actively taken up plants they are liable for leaching losses (Bolan et al., 2003). The addition of lime to a soil neutralizes its active acidity through chemical reactions that remove hydrogen ions from the soil solution. Though, there are also acidic cations $\left(\mathrm{H}^{+}\right.$and $\mathrm{Al}^{3+}$ ) adsorbed on the soil colloids which can be discharged into the soil solution to exchange those neutralized by the lime. These values (exchangeable acidity) ranged from 0.19 3.51 meq $100 \mathrm{~g}^{-1}$ with mean values of $0.14,2.17,0.74$ and 0.17 meq $100 \mathrm{~g}^{-1}$ for Achialum, Meupi, Nepele and Ala'amiti sites respectively. Thus, to effectively raise the $\mathrm{pH}$ of the soils studied, both active and exchangeable acidity must be neutralized. Exchangeable acidity, which is reported in units of meq $100 \mathrm{~g}^{-1}$ soil, is directly related to the quantity of lime required to increase the $\mathrm{pH}$ of a soil from its current level to the target level determined by the selected crop (Spargo et al., 2013; Njoyim et al., 2016b). From the values of soil pH and exchangeable acidity, soils of Meupi were the most acidic and had the highest exchangeable acidity. Thus, the order of lime requirement for the soils is Meupi $>$ Nepele $>$ Ala'amiti $>$ Achialum. The electrical conductivities of the soils were generally low and the values ranged from $0.02-0.11 \mathrm{mS} \mathrm{cm}^{-1}$ with mean values of $0.03,0.06,0.08$ and $0.06 \mathrm{mS} \mathrm{cm}^{-1}$ for Achialum, Meupi, Nepele and Ala'amiti sites, respectively. The EC value reflects the amount of soluble salts in an extract and therefore provides an indication of soil salinity. Low values of electrical conductivities obtained showed that the soils are suitable for crop production. Horneck et al. (2011) reported that soil with EC values less than $1 \mathrm{mS} \mathrm{cm}^{-1}$ are suitable for crop production. The organic matter content was found to be average with values ranging from $2.10-14.99 \%$ and with mean values of $11.69,6.84,4.44$ and $8.40 \%$ for Achialum, Meupi, Nepele and Ala'amiti sites respectively. The total nitrogen content was very low in all the soils $(\mathrm{N}<1 \%)$. The $\mathrm{C} /$ $\mathrm{N}$ ratio for most of the soils was high with values ranging from 2.59-64.76, with mean values of 33.41, 34.31, 17.56 and 27.88 for Achialum, Meupi, Nepele and Ala'amiti sites respectively. High $\mathrm{C} / \mathrm{N}$ ratios indicated that the organic matter content was poorly mineralised (immobilization was highly favoured). High soil $\mathrm{C} / \mathrm{N}$ ratio could slow down the decomposition rate of $\mathrm{OM}$ and organic $\mathrm{N}$ by limiting the soil microbial activity's ability with lower mobilization of $\mathrm{N}$. Low soil $\mathrm{C} / \mathrm{N}$ ratio on contrary, could accelerate the process of microbial decomposition of OM and $\mathrm{N}$ (Tsozue et al., 2016). Njoyim et al. $(2016 \mathrm{a}, \mathrm{b})$ reported similar results for $\mathrm{C} / \mathrm{N}$ ratio on the soils of Foumbot and mount Bambouto in the West region of Cameroon. The available phosphorus in the soils was low with values ranging from $1.55-14.26 \mathrm{mg} \mathrm{kg}^{-1}$ and with mean values of $3.26,5.92,8.67$ and $4.28 \mathrm{mg} / \mathrm{kg}$ for Achialum, Meupi, Nepele and Ala'amiti sites respectively. Phosphorus soil tests are an index of $\mathrm{P}$ availability (low, medium, high, excess). The phosphorus application rate necessary to correct $\mathrm{P}$ deficiencies varies depending on soil properties and the crop grown. In many situations, banded phosphorus applications are more effective than broadcast applications, especially when $\mathrm{P}$ soil test values are low as in the soils studied (Silva and Uchida, 2002). Cation exchange capacity (CEC) was high with values ranging from $11.20-35.20$ meq $100 \mathrm{~g}^{-1}$, with mean values of $32.30,22.27,28.48$ and $27.23 \mathrm{meq} 100 \mathrm{~g}^{-1}$ for Achialum, Meupi, Nepele and Ala'amiti sites respectively. Cation Exchange Capacity can range from below 5 meq $100 \mathrm{~g}^{-}$ ${ }^{1}$ in sandy low organic matter soils to over $15 \mathrm{meq} 100 \mathrm{~g}^{-1}$ in finer textured soils and those high in organic matter. Low CEC soils are more susceptible to cation nutrient loss through leaching (Spargo et al., 2013). Results of low available P and high CEC conform to those of Tematio et al. (2004) and Bitondo et al. (2013) reported on the soils of mount Bambouto (Awing is surrounded by an extension of the volcanic chain of the Bambouto Mountain). The sum of the exchangeable bases was average with values ranging from $2.22-14.33 \mathrm{meq} 100 \mathrm{~g}^{-}$ ${ }^{1}$, with mean values of $9.86,5.62,7.81$ and 8.24 meq $100 \mathrm{~g}^{-1}$ for Achialum, Meupi, Nepele and Ala'amiti sites respectively. Base saturation which is the percentage of the soil CEC that is occupied by basic cations (calcium, magnesium, potassium, sodium) at the current soil $\mathrm{pH}$ value was less than $50 \%$ for all the soils, a fact which shows that the soils studied are acidic in nature (Njoyim et al., 2016b). Results of particle size analysis showed that the soil textural class was loam, clay loam, loam and sand clay loam for Achialum, Meupi, Nepele and Ala'amiti sites, respectively. Soil texture is important because it influences water and nutrient holding capacity, drainage, aeration, susceptibility to compaction, irrigation and planting practices, and erodability. For example, coarse-textured soils such as sand, loamy sand or sandy loam, have a low water holding capacity, drain quickly, and are low in nutrients, especially for nitrogen and potassium. Medium-textured soils which characterises the soils studied usually have good drainage and adequate water and nutrient holding capacity. Fine textured soils such as clay loam and clay, have a high water and nutrient holding capacity, but are usually poorly drained and are difficult to manage when wet. These soils must often be tiled to improve crop productivity (Schroeder et al., 2007). Results of total and available (Melich 3 exchangeable) heavy metal analyses for Achialum (AC), Meupi (ME), Nepele (NE) and Ala'amiti (AL) samples are presented in Tables 2 and 3, respectively. These results are discussed with respect to standards set by FAO/WHO (2011).

Zinc (Zn): The mean total concentration of zinc in the soil samples were $26.85,25.10,23.25$ and $30.68 \mathrm{mg} \mathrm{kg}^{-1}$ soil, while the mean available concentrations were $0.75,2.73,0.24$, and $1.01 \mathrm{mg} \mathrm{kg}^{-1}$ soil for Achialum, Meupi, Nepele and Ala'amiti sites respectively. In almost all the soil samples, the concentration of zinc was recorded below the permissible 
limit set by FAO/WHO $\left(2.0 \mathrm{mg} \mathrm{kg}^{-1}\right)$. Zinc is one of the important trace elements that play a vital role in the physiological and metabolic process of many organisms. Nevertheless, higher concentrations of zinc can be toxic to the organism. It plays an important role in protein synthesis and is a metal which shows fairly low concentration in surface water due to its restricted mobility from the place of rock weathering or from the natural sources (Ruqia et al., 2015).

Copper (Cu): The mean total concentration of copper in the soil samples were $19.00,13.39,23.23$ and $11.51 \mathrm{mg} \mathrm{kg}^{-1}$ soil, while the mean available concentrations were 1.13, 5.13, 1.38, and $0.64 \mathrm{mg} \mathrm{kg}^{-1}$ soil for Achialum, Meupi, Nepele and Ala'amiti sites respectively. The concentration of copper in all the soil samples was above the maximum permissible limit set by $\mathrm{FAO} / \mathrm{WHO}\left(0.20 \mathrm{mg} \mathrm{kg}^{-1}\right)$. Copper accumulates in liver and brain and its toxicity is a fundamental cause of Wilson's disease. Copper particulates are released into the atmosphere by windblown dust; volcanic eruptions; and anthropogenic sources, primarily copper smelters and ore processing facilities (Ruqia et al., 2015).

Manganese (Mn): The mean total concentration of manganese in the soil samples were 1787.48, 384.35, 1599.97 and $1813.48 \mathrm{mg} \mathrm{kg}^{-1}$ soil, while the mean available concentrations were $34.24,13.79,34.51$, and $30.07 \mathrm{mg} \mathrm{kg}^{-1}$ soil for Achialum, Meupi, Nepele and Ala'amiti sites respectively. The concentration of $\mathrm{Mn}$ in all the soil samples was above the maximum permissible limit set by FAO/WHO $\left(0.20 \mathrm{mg} \mathrm{kg}^{-1}\right)$. These very high concentrations of total and available $\mathrm{Mn}$ could be from the soil parent materials (basalt, trachytes and rhyolite) which are natural sources of $\mathrm{Mn}$ in the soil. Since the soils were very acidic, Mn solubility was highly favoured leading to high available concentrations.

Iron (Fe): The mean total concentration of iron in the soil samples were $86980.28,76999.62,185950.16$ and 115673.59 $\mathrm{mg} \mathrm{kg}^{-1}$ soil, while the mean available concentrations were 45.00, 92.27, 29.42, and $61.99 \mathrm{mg} \mathrm{kg}^{-1}$ soil for Achialum, Meupi, Nepele and Ala'amiti sites respectively. The concentration of $\mathrm{Fe}$ in all the soil samples was above the maximum permissible limit set by FAO/WHO $\left(5.0 \mathrm{mg} \mathrm{kg}^{-1}\right)$. Very high concentrations of total and available Fe could be from the soil parent materials (basalt, trachytes and rhyolite) which are natural sources of $\mathrm{Fe}$ in the soil. Strong Fe concretions were also very visible in all the soil profiles. Also, since the soils were very acidic, Fe solubility was highly favoured leading to high available concentrations. Excess amount of iron (more than $10 \mathrm{mg} \mathrm{kg}^{-1}$ ) causes rapid increase in pulse rate and coagulation of blood in blood vessels, hypertension and drowsiness (Ruqia et al., 2015).

Lead (Pb): The mean total concentration of lead in the soil samples were 20.36, 16.86, 13.46 and $16.99 \mathrm{mg} \mathrm{kg}^{-1}$ soil, while the mean available concentrations were $0.00,0.80,0.00$, and $0.00 \mathrm{mg} \mathrm{kg}^{-1}$ soil for Achialum, Meupi, Nepele and Ala'amiti sites respectively. In almost all the collected soil samples, concentration of lead was recorded below the permissible limit set by FAO/WHO $\left(0.35 \mathrm{mg} \mathrm{kg}^{-1}\right)$. There has been a lot of attention paid to lead levels in soil because it is well-known to cause adverse health effects, and is relatively widespread as a result of its historical use in many commercial products, from gasoline to paint. It accumulates with age in bones aorta, and kidney, liver and spleen. It can enter the human body through uptake of food $(65 \%)$, water $(20 \%)$ and air (15\%) (Ruqia et al., 2015).

Nickel (Ni): The mean total concentration of nickel in the soil samples were $79.06,22.73,78.59$ and $75.11 \mathrm{mg} \mathrm{kg}^{-1}$ soil, while the mean available concentrations were 4.54, 2.04, 0.24, and $4.50 \mathrm{mg} \mathrm{kg}^{-1}$ soil for Achialum, Meupi, Nepele and Ala'amiti sites respectively. The concentration of $\mathrm{Ni}$ in almost all soil samples was above the maximum permissible limit set by $\mathrm{FAO} / \mathrm{WHO}\left(0.20 \mathrm{mg} \mathrm{kg}^{-1}\right)$. Nickel has been considered to be an essential trace element for human and animal health (Ruqia et al., 2015).

Chromium (Cr): The mean total concentration of chromium in the soil samples were 102.00, 32.00, 138.80 and $102.20 \mathrm{mg}$ $\mathrm{kg}^{-1}$ soil, while the mean available concentrations were 1.39 , $0.71,0.68$, and $0.71 \mathrm{mg} \mathrm{kg}^{-1}$ soil for Achialum, Meupi, Nepele and Ala'amiti sites respectively. In all the collected soil samples concentration of chromium was recorded above the permissible limit set by FAO/WHO $\left(0.50 \mathrm{mg} \mathrm{kg}^{-1}\right)$. In a small amount, chromium stimulates the growth of agricultural crops; an excess of it however promotes various diseases. A wide distribution of $\mathrm{Cr}$ in the environment is unfavourable for humans and animals. Chromium toxicity depends on its oxidation status. Cr occurs in two states in soils. The oxyanion chromate $\mathrm{CrO}_{4}{ }^{2-}$, is highly mobile and more toxic in soils and groundwater. On the contrary, the reduced ion $\mathrm{Cr}$ (III) forms either a weakly soluble hydroxide or stable complexes with soil minerals (Vodyanitskii, 2016).

Cadmium (Cd): The mean total concentration of cadmium in the soil samples were $5.31,3.96,7.92$ and $5.32 \mathrm{mg} \mathrm{kg}^{-1}$ soil, while the mean available concentrations were $0.47,0.30,0.45$, and $0.47 \mathrm{mg} \mathrm{kg}^{-1}$ soil for Achialum, Meupi, Nepele and Ala'amiti sites respectively. In all the collected soil samples concentration of cadmium was recorded above the maximum permissible limit set by FAO/WHO $\left(0.05 \mathrm{mg} \mathrm{kg}^{-1}\right)$. High Cd values may have resulted from repeated use of fertilizers which are sources of $\mathrm{Cd}$ in the soil.

Arsenic (As): The concentration of arsenic in all the samples was not detectable. Gross content of heavy metals in a soil includes inert (usually silicate) form of heavy metals, which has no toxic effect on plants and soil biota (Vodyanitskii, 2016). That is why mobile content, easily soluble (potentially toxic) compounds of heavy metals are the reference concentrations used in this discussion. Vodyanitskii (2016) reported high variation by year of mobile forms of heavy metals in soils: from $45 \%(\mathrm{Mn})$, up $188 \%(\mathrm{Cd})$. Variation depends on weather conditions and, above all, rainfall and soil moisture. At the same venue, there are significant differences in the concentration of mobile forms of heavy metals in a year. Such a strong variation in the contents of mobile forms of heavy metals is due to the activities of soil organisms, rhythmic changes in chemical elements acquisitions by plants and other factors (Hamel et al., 2010). To use mobile forms of heavy metals for soil contamination assessment, it is important to standardize the procedure for selection of a soil sample. Vodyanitskii (2016) reported that it is necessary to come to an agreement, in what period of the year soil sampling should be done and that it is best to select a soil sample in the rainy season when soil moisture is maximal and slightly varies from year to year, rather than in the dry season, when humidity varies strongly and during the season and from year to year. Significant correlations $(\mathrm{p}<0.05)$ were recorded between most soil physicochemical properties (Table 4). $\mathrm{pH}-\mathrm{H}_{2} \mathrm{O}$ and $\mathrm{pH}-\mathrm{KCl}$ correlated negatively with exchangeable acidity with correlation coefficient values (r) of -0.959 and -0.976 , respectively. This results shows that an increase in soil $\mathrm{pH}$ helps reduces acidic cations $\left(\mathrm{H}^{+}\right.$and $\left.\mathrm{Al}^{3+}\right)$ on the soil colloid, there by favouring the availability of plant nutrients. Organic matter 
Table 1. Physico-chemical characteristics of soil at different sites.

\begin{tabular}{|c|c|c|c|c|c|c|c|c|c|c|c|c|}
\hline Site & $\begin{array}{c}\text { Sample } \\
\text { no. }\end{array}$ & $\begin{array}{c}\rho \\
\left(\mathrm{g} \mathrm{cm}^{-3}\right)\end{array}$ & $\begin{array}{l}\text { pH- } \\
\mathrm{H}_{2} \mathrm{O}\end{array}$ & $\begin{array}{l}\text { pH- } \\
\text { KCl }\end{array}$ & $\Delta \mathrm{pH}$ & $\begin{array}{c}\text { EA } \\
\left({\left.\operatorname{meq~} 100 g^{-1}\right)}^{-1}\right)\end{array}$ & $\begin{array}{c}\mathrm{EC} \\
\left(\mathrm{mS} \mathrm{cm}^{-1}\right)\end{array}$ & $\begin{array}{l}\% \\
\text { OC }\end{array}$ & $\begin{array}{c}\% \\
\text { OM }\end{array}$ & $\% \mathrm{~N}$ & $\mathbf{C} / \mathbf{N}$ & $\begin{array}{c}\text { Avail P } \\
\left(\mathrm{mg} \mathrm{kg}^{-1}\right)\end{array}$ \\
\hline \multirow[t]{6}{*}{$\mathrm{AC}$} & 1 & 0.77 & 6.00 & 4.90 & -1.10 & 0.00 & 0.04 & 6.09 & 10.49 & 0.17 & 35.87 & 5.13 \\
\hline & 2 & 0.78 & 5.80 & 4.60 & -1.20 & 0.00 & 0.03 & 8.70 & 14.99 & 0.25 & 34.41 & 2.38 \\
\hline & 3 & 0.76 & 5.70 & 4.60 & -1.10 & 0.00 & 0.02 & 5.22 & 8.99 & 0.20 & 26.09 & 4.47 \\
\hline & 4 & 0.77 & 5.20 & 4.40 & -0.80 & 0.71 & 0.03 & 8.70 & 14.99 & 0.19 & 45.84 & 1.88 \\
\hline & 5 & 0.78 & 5.60 & 4.60 & -1.00 & 0.00 & 0.04 & 5.22 & 8.99 & 0.21 & 24.84 & 2.42 \\
\hline & Mean values & 0.77 & 5.66 & 4.62 & -1.04 & 0.14 & 0.03 & 6.78 & 11.69 & 0.20 & 33.41 & 3.26 \\
\hline \multirow[t]{6}{*}{ ME } & 1 & 0.89 & 4.30 & 4.10 & -0.20 & 0.43 & 0.03 & 9.57 & 16.49 & 0.15 & 64.76 & 14.26 \\
\hline & 2 & 0.89 & 4.30 & 4.00 & -0.30 & 1.65 & 0.05 & 4.35 & 7.50 & 0.09 & 48.31 & 1.55 \\
\hline & 3 & 0.88 & 4.40 & 3.90 & -0.50 & 3.51 & 0.09 & 0.87 & 1.50 & 0.13 & 6.50 & 2.93 \\
\hline & 4 & 0.85 & 4.10 & 4.0 & -0.10 & 2.73 & 0.03 & 0.70 & 1.20 & 0.11 & 6.32 & 2.60 \\
\hline & 5 & 0.87 & 4.50 & 3.90 & -0.60 & 2.54 & 0.08 & 4.35 & 7.50 & 0.10 & 45.67 & 8.26 \\
\hline & Mean values & 0.88 & 4.32 & 3.98 & -0.34 & 2.17 & 0.06 & 3.97 & 6.84 & 0.12 & 34.31 & 5.92 \\
\hline \multirow[t]{6}{*}{ NE } & 1 & 0.76 & 5.70 & 4.80 & -0.90 & 0.00 & 0.05 & 1.22 & 2.10 & 0.49 & 2.50 & 2.87 \\
\hline & 2 & 0.78 & 5.30 & 4.17 & -1.13 & 3.01 & 0.06 & 4.00 & 6.90 & 0.18 & 21.83 & 9.54 \\
\hline & 3 & 0.76 & 5.50 & 4.70 & -0.80 & 0.00 & 0.11 & 2.61 & 4.50 & 0.11 & 23.72 & 9.15 \\
\hline & 4 & 0.77 & 5.70 & 4.50 & -1.20 & 0.71 & 0.11 & 2.43 & 4.20 & 0.12 & 21.13 & 12.77 \\
\hline & 5 & 0.76 & 5.40 & 4.70 & -0.70 & 0.19 & 0.05 & 2.61 & 4.50 & 0.14 & 18.63 & 8.99 \\
\hline & Mean values & 0.77 & 5.52 & 4.57 & -0.95 & 0.74 & 0.08 & 2.57 & 4.44 & 0.21 & 17.56 & 8.67 \\
\hline \multirow[t]{6}{*}{$\mathrm{AL}$} & 1 & 0.83 & 5.20 & 4.50 & -0.70 & 0.69 & 0.03 & 3.48 & 6.00 & 0.23 & 15.15 & 6.43 \\
\hline & 2 & 0.86 & 5.30 & 4.40 & -0.90 & 0.86 & 0.05 & 5.22 & 8.99 & 0.16 & 32.61 & 5.38 \\
\hline & 3 & 0.88 & 5.60 & 4.90 & -0.70 & 0.00 & 0.10 & 6.09 & 10.49 & 0.18 & 34.64 & 2.21 \\
\hline & 4 & 0.82 & 5.50 & 4.60 & -0.90 & 0.00 & 0.07 & 3.48 & 6.00 & 0.17 & 20.46 & 4.15 \\
\hline & 5 & 0.85 & 5.70 & 4.70 & -1.00 & 0.00 & 0.06 & 6.09 & 10.49 & 0.17 & 36.54 & 3.25 \\
\hline & Mean values & 0.85 & 5.46 & 4.62 & -0.84 & 0.17 & 0.06 & 4.87 & 8.40 & 0.18 & 27.88 & 4.28 \\
\hline
\end{tabular}

$\Delta \mathrm{pH}=$ Net charge $\left(\mathrm{pH} \mathrm{KCl}-\mathrm{pH} \mathrm{H}_{2} \mathrm{O}\right), \mathrm{EA}=$ Exchangeable Acidity, $\mathrm{EC}=$ Electrical Conductivity, $\mathrm{OC}=$ Organic Carbon, $\mathrm{OM}=$ Organic Matter, $\mathrm{N}=$ Total Nitrogen, $\mathrm{C} / \mathrm{N}=$ Mineralization factor, Avail. $\mathrm{P}=$ Available phosphorus.

Table 1. Contd...

\begin{tabular}{|c|c|c|c|c|c|c|c|c|c|c|c|c|}
\hline Site & $\begin{array}{c}\text { Sample } \\
\text { no. }\end{array}$ & $\begin{array}{c}\text { CEC } \\
\left(\mathrm{meq}^{-}\right. \\
\left.100 \mathrm{~g}^{-1}\right)\end{array}$ & $\begin{array}{c}\begin{array}{c}\text { Ca } \\
(\mathrm{meq} \\
\left.100 \mathrm{~g}^{-1}\right)\end{array} \\
\end{array}$ & $\begin{array}{c}\mathrm{Mg} \\
\left(\mathrm{meq}^{-}\right. \\
\left.100 \mathrm{~g}^{-1}\right)\end{array}$ & $\begin{array}{c}\mathrm{Na} \\
(\mathrm{meq} \\
\left.100 \mathrm{~g}^{-1}\right)\end{array}$ & $\begin{array}{c}\begin{array}{c}\mathrm{K} \\
(\mathrm{meq} \\
\left.100 \mathrm{~g}^{-1}\right)\end{array} \\
\end{array}$ & $\begin{array}{c}\text { Sum } \\
\text { (Bases) }\end{array}$ & $\begin{array}{c}\text { Base } \\
\text { Saturation } \\
(\%)\end{array}$ & $\begin{array}{c}\text { Sand } \\
(\%)\end{array}$ & $\begin{array}{l}\text { Silt } \\
(\%)\end{array}$ & $\begin{array}{l}\text { Clay } \\
(\%)\end{array}$ & $\begin{array}{c}\text { Textural } \\
\text { Class" }\end{array}$ \\
\hline \multirow[t]{6}{*}{$\mathrm{AC}$} & 1 & 32.80 & 9.95 & 0.16 & 1.05 & 3.17 & 14.33 & 43.69 & 41 & 36 & 23 & $\mathrm{~L}$ \\
\hline & 2 & 28.24 & 4.64 & 2.56 & 0.84 & 2.29 & 10.33 & 36.57 & 47 & 39 & 14 & $\mathrm{~L}$ \\
\hline & 3 & 35.20 & 8.64 & 0.48 & 0.49 & 0.65 & 10.25 & 29.13 & 46 & 31 & 23 & $\mathrm{~L}$ \\
\hline & 4 & 33.92 & 5.44 & 0.16 & 0.34 & 0.29 & 6.23 & 18.35 & 42 & 37 & 21 & $\mathrm{~L}$ \\
\hline & 5 & 31.36 & 4.64 & 2.56 & 0.34 & 0.65 & 8.18 & 26.09 & 42 & 34 & 24 & $\mathrm{~L}$ \\
\hline & Mean values & 32.30 & 8.66 & 1.18 & 0.61 & 1.41 & 9.86 & 37.28 & 43 & 35 & 21 & $\mathrm{~L}$ \\
\hline \multirow[t]{6}{*}{ ME } & 1 & 16.88 & 5.12 & 1.60 & 0.34 & 0.29 & 7.35 & 43.51 & 22 & 45 & 33 & $\mathrm{CL}$ \\
\hline & 2 & 11.20 & 1.12 & 0.48 & 0.49 & 0.13 & 2.22 & 19.79 & 22 & 48 & 30 & $\mathrm{CL}$ \\
\hline & 3 & 23.44 & 4.96 & 1.12 & 0.49 & 0.46 & 7.03 & 29.98 & 22 & 42 & 36 & $\mathrm{CL}$ \\
\hline & 4 & 31.36 & 3.68 & 1.12 & 0.49 & 0.13 & 5.42 & 17.27 & 24 & 42 & 34 & $\mathrm{CL}$ \\
\hline & 5 & 28.48 & 3.84 & 1.76 & 0.20 & 0.31 & 6.11 & 21.46 & 24 & 40 & 36 & $\mathrm{CL}$ \\
\hline & Mean values & 22.27 & 3.74 & 1.22 & 0.40 & 0.26 & 5.62 & 26.41 & 22 & 43 & 33 & $\mathrm{CL}$ \\
\hline \multirow[t]{6}{*}{ NE } & 1 & 30.72 & 7.36 & 5.44 & 0.20 & 0.16 & 13.17 & 42.86 & 47 & 30 & 23 & $\mathrm{~L}$ \\
\hline & 2 & 28.16 & 5.76 & 0.32 & 0.34 & 0.36 & 6.78 & 24.07 & 46 & 30 & 24 & $\mathrm{~L}$ \\
\hline & 3 & 25.44 & 3.04 & 0.48 & 0.34 & 0.16 & 4.02 & 15.80 & 43 & 32 & 25 & $\mathrm{~L}$ \\
\hline & 4 & 30.72 & 3.84 & 0.32 & 0.34 & 0.12 & 4.61 & 15.02 & 46 & 28 & 26 & SCL \\
\hline & 5 & 27.36 & 5.60 & 4.32 & 0.34 & 0.21 & 10.47 & 38.26 & 47 & 30 & 23 & $\mathrm{~L}$ \\
\hline & Mean values & 28.48 & 5.12 & 2.18 & 0.31 & 0.20 & 7.81 & 27.20 & 46 & 30 & 24 & $\mathrm{~L}$ \\
\hline \multirow[t]{6}{*}{$\mathrm{AL}$} & 1 & 30.40 & 3.52 & 0.48 & 0.20 & 0.16 & 4.37 & 14.36 & 55 & 19 & 26 & $\mathrm{SCL}$ \\
\hline & 2 & 24.00 & 4.00 & 4.00 & 0.34 & 0.31 & 8.65 & 36.03 & 60 & 15 & 25 & SCL \\
\hline & 3 & 31.36 & 11.84 & 1.12 & 0.20 & 0.21 & 13.37 & 42.65 & 47 & 28 & 25 & SCL \\
\hline & 4 & 23.84 & 3.84 & 0.16 & 0.20 & 0.21 & 4.41 & 18.51 & 42 & 31 & 27 & $\mathrm{CL}$ \\
\hline & 5 & 26.56 & 5.12 & 4.64 & 0.34 & 0.31 & 10.41 & 39.18 & 56 & 18 & 26 & $\mathrm{SCL}$ \\
\hline & Mean values & 27.23 & 5.66 & 2.08 & 0.25 & 0.24 & 8.24 & 30.15 & 52 & 22 & 25 & SCL \\
\hline
\end{tabular}


Table 2. Total heavy and trace elemental concentrations in the soil at different sites.

\begin{tabular}{|c|c|c|c|c|c|c|c|c|c|c|}
\hline Site & $\begin{array}{c}\text { Sample } \\
\text { no. }\end{array}$ & $\begin{array}{c}\mathrm{Zn} \\
\left(\mathrm{mg} \mathrm{kg}^{-1}\right)\end{array}$ & $\begin{array}{c}\mathrm{Cu} \\
\left(\mathrm{mg} \mathrm{kg}^{-1}\right)\end{array}$ & $\begin{array}{c}\mathrm{Mn} \\
\left(\mathrm{mg} \mathrm{kg}^{-1}\right)\end{array}$ & $\begin{array}{c}\mathrm{Fe} \\
\left(\mathrm{mg} \mathrm{kg}^{-1}\right)\end{array}$ & $\begin{array}{c}\mathrm{Pb} \\
\left(\mathrm{mg} \mathrm{kg}^{-1}\right)\end{array}$ & $\begin{array}{c}\mathrm{Ni} \\
\left(\mathrm{mg} \mathrm{kg}^{-1}\right)\end{array}$ & $\begin{array}{c}\mathrm{Cr} \\
\left(\mathrm{mg} \mathrm{kg}^{-1}\right)\end{array}$ & $\begin{array}{c}\text { Cd } \\
\left(\mathrm{mg} \mathrm{kg}^{-1}\right)\end{array}$ & $\underset{\left(\mathrm{mg} \mathrm{kg}^{-1}\right)}{\mathrm{As}}$ \\
\hline \multirow[t]{5}{*}{$\mathrm{AC}$} & 1 & 24.75 & 16.00 & 1786.77 & 85680.99 & 19.98 & 76.43 & 99.00 & 4.34 & ND \\
\hline & 2 & 28.45 & 17.35 & 1798.25 & 88242.58 & 22.21 & 85.33 & 106.55 & 6.56 & ND \\
\hline & 3 & 25.86 & 20.33 & 1765.98 & 86574.64 & 20.24 & 78.67 & 100.45 & 5.23 & ND \\
\hline & 4 & 27.84 & 21.20 & 1809.67 & 87297.86 & 20.01 & 77.88 & 102.65 & 6.11 & ND \\
\hline & 5 & 27.36 & 20.12 & 1776.75 & 87105.33 & 19.36 & 76.99 & 101.35 & 4.31 & ND \\
\hline \multicolumn{2}{|c|}{ Mean values } & 26.85 & 19.00 & 1787.48 & 86980.28 & 20.36 & 79.06 & 102.00 & 5.31 & ND \\
\hline \multirow[t]{5}{*}{ ME } & 1 & 25.34 & 14.11 & 398.21 & 77001.21 & 17.86 & 23.21 & 33.01 & 3.99 & ND \\
\hline & 2 & 26.43 & 13.45 & 358.22 & 77012.34 & 15.86 & 22.97 & 32.89 & 4.05 & ND \\
\hline & 3 & 24.44 & 12.98 & 386.99 & 76996.99 & 15.95 & 21.88 & 32.86 & 3.66 & ND \\
\hline & 4 & 25.45 & 14.00 & 380.44 & 76995.76 & 15.76 & 22.58 & 30.26 & 3.98 & ND \\
\hline & 5 & 23.84 & 12.41 & 397.89 & 77991.80 & 18.87 & 23.01 & 30.86 & 4.12 & ND \\
\hline \multicolumn{2}{|c|}{ Mean values } & 25.10 & 13.39 & 384.35 & 76999.62 & 16.86 & 22.73 & 32.00 & 3.96 & ND \\
\hline \multirow[t]{6}{*}{$\mathrm{NE}$} & 1 & 23.56 & 22.78 & 1601.45 & 188869.03 & 14.66 & 79.65 & 137.87 & 8.25 & ND \\
\hline & 2 & 23.87 & 24.11 & 1598.98 & 184978.64 & 12.98 & 80.01 & 140.05 & 7.98 & ND \\
\hline & 3 & 22.99 & 23.66 & 1587.57 & 185689.87 & 13.91 & 78.98 & 139.33 & 8.00 & ND \\
\hline & 4 & 23.65 & 23.32 & 1600.76 & 186856.09 & 13.33 & 77.50 & 136.99 & 6.98 & ND \\
\hline & 5 & 22.18 & 22.26 & 1611.09 & 183357.17 & 12.42 & 76.81 & 139.76 & 8.39 & ND \\
\hline & Mean values & 23.25 & 23.23 & 1599.97 & 185950.16 & 13.46 & 78.59 & 138.80 & 7.92 & ND \\
\hline \multirow[t]{6}{*}{$\mathrm{AL}$} & 1 & 31.45 & 11.58 & 1814.56 & 115687.65 & 16.89 & 76.10 & 102.55 & 5.45 & ND \\
\hline & 2 & 29.67 & 12.89 & 1812.98 & 115654.87 & 17.75 & 76.34 & 100.65 & 5.89 & ND \\
\hline & 3 & 29.76 & 11.97 & 1813.67 & 115700.01 & 15.98 & 75.32 & 99.98 & 4.90 & ND \\
\hline & 4 & 30.98 & 11.01 & 1814.00 & 115598.34 & 16.55 & 74.10 & 101.23 & 5.00 & ND \\
\hline & 5 & 31.54 & 10.10 & 1812.19 & 115727.08 & 17.78 & 73.69 & 106.59 & 5.36 & ND \\
\hline & Mean values & 30.68 & 11.51 & 1813.48 & 115673.59 & 16.99 & 75.11 & 102.2 & 5.32 & ND \\
\hline
\end{tabular}

ND $=$ Not detected

Table 3. Available (Melich 3 exchangeable) heavy and trace elemental concentrations in the soil at different sites.

\begin{tabular}{|c|c|c|c|c|c|c|c|c|c|c|}
\hline Site & $\begin{array}{c}\text { Sample } \\
\text { no. }\end{array}$ & $\begin{array}{c}\mathrm{Zn} \\
\left(\mathrm{mg} \mathrm{kg}^{-1}\right)\end{array}$ & $\underset{\left(\mathrm{mg} \mathrm{kg}^{-1}\right)}{\mathrm{Cu}}$ & $\underset{\left(\mathrm{mg} \mathrm{kg}^{-1}\right)}{\mathrm{Mn}}$ & $\begin{array}{c}\mathrm{Fe} \\
\left(\mathrm{mg} \mathrm{kg}^{-1}\right)\end{array}$ & $\begin{array}{c}\mathrm{Pb} \\
\left(\mathrm{mg} \mathrm{kg}^{-1}\right)\end{array}$ & $\begin{array}{c}\mathrm{Ni} \\
\left(\mathrm{mg} \mathrm{kg}^{-1}\right)\end{array}$ & $\underset{\left(\mathrm{mg} \mathrm{kg}^{-1}\right)}{\mathrm{Cr}}$ & $\begin{array}{c}\mathrm{Cd} \\
\left(\mathrm{mg} \mathrm{kg}^{-1}\right)\end{array}$ & $\underset{\left(\mathrm{mg} \mathrm{kg}^{-1}\right)}{\mathrm{As}}$ \\
\hline \multirow[t]{6}{*}{$\mathrm{AC}$} & 1 & 0.75 & 1.14 & 32.55 & 44.49 & 0.00 & 5.83 & 1.35 & 0.45 & ND \\
\hline & 2 & 0.65 & 1.13 & 35.25 & 46.38 & 0.00 & 4.33 & 1.55 & 0.50 & ND \\
\hline & 3 & 0.86 & 1.11 & 33.98 & 43.94 & 0.00 & 4.67 & 1.45 & 0.46 & ND \\
\hline & 4 & 0.84 & 1.15 & 34.67 & 44.86 & 0.00 & 3.88 & 1.25 & 0.49 & ND \\
\hline & 5 & 0.65 & 1.12 & 34.75 & 45.33 & 0.00 & 3.99 & 1.35 & 0.45 & ND \\
\hline & Mean values & 0.75 & 1.13 & 34.24 & 45.00 & 0.00 & 4.54 & 1.39 & 0.47 & ND \\
\hline \multirow[t]{6}{*}{$\mathrm{ME}$} & 1 & 3.00 & 4.81 & 15.41 & 92.46 & 0.60 & 2.19 & 0.88 & 0.40 & ND \\
\hline & 2 & 2.92 & 5.45 & 13.22 & 92.34 & 0.82 & 1.97 & 0.69 & 0.32 & ND \\
\hline & 3 & 2.44 & 4.98 & 12.99 & 91.99 & 0.95 & 1.98 & 0.86 & 0.27 & ND \\
\hline & 4 & 2.45 & 5.00 & 13.44 & 92.76 & 0.76 & 2.05 & 0.26 & 0.29 & ND \\
\hline & 5 & 2.84 & 5.41 & 13.89 & 91.80 & 0.87 & 2.01 & 0.86 & 0.22 & ND \\
\hline & Mean values & 2.73 & 5.13 & 13.79 & 92.27 & 0.80 & 2.04 & 0.71 & 0.30 & ND \\
\hline \multirow[t]{6}{*}{ NE } & 1 & 0.21 & 1.55 & 36.51 & 28.48 & 0.00 & 0.09 & 0.76 & 0.43 & ND \\
\hline & 2 & 0.17 & 1.11 & 33.98 & 29.64 & 0.00 & 0.12 & 0.56 & 0.44 & ND \\
\hline & 3 & 0.29 & 1.66 & 34.57 & 29.87 & 0.00 & 0.28 & 0.33 & 0.51 & ND \\
\hline & 4 & 0.35 & 1.32 & 33.76 & 30.09 & 0.00 & 0.50 & 0.99 & 0.48 & ND \\
\hline & 5 & 0.18 & 1.26 & 34.09 & 29.17 & 0.00 & 0.21 & 0.76 & 0.39 & ND \\
\hline & Mean Values & 0.24 & 1.38 & 34.51 & 29.42 & 0.00 & 0.24 & 0.68 & 0.45 & ND \\
\hline \multirow[t]{6}{*}{$\mathrm{AL}$} & 1 & 0.76 & 0.80 & 28.59 & 62.65 & 0.00 & 4.05 & 0.55 & 0.20 & ND \\
\hline & 2 & 1.03 & 0.49 & 29.98 & 61.87 & 0.00 & 4.34 & 0.65 & 0.79 & ND \\
\hline & 3 & 1.06 & 0.57 & 29.67 & 63.01 & 0.00 & 4.32 & 0.98 & 0.60 & ND \\
\hline & 4 & 1.18 & 0.69 & 30.00 & 60.34 & 0.00 & 5.10 & 0.78 & 0.40 & ND \\
\hline & 5 & 1.02 & 0.65 & 31.11 & 62.08 & 0.00 & 4.69 & 0.59 & 0.36 & ND \\
\hline & Mean values & 1.01 & 0.64 & 30.07 & 61.99 & 0.00 & 4.50 & 0.71 & 0.47 & ND \\
\hline
\end{tabular}


Table 4. Pearson correlation coefficient matrix between physico-chemical properties of the soils.

\begin{tabular}{|c|c|c|c|c|c|c|c|c|c|c|c|c|c|}
\hline & BD & $\mathrm{pH}-\mathrm{H}_{2} \mathrm{O}$ & pH-KCl & EA & EC & OM & $\mathbf{N}$ & Avail. P & CEC & Sum & Sand & Silt & Clay \\
\hline BD & 1 & & & & & & & & & & & & \\
\hline $\mathrm{pH}-\mathrm{H}_{2} \mathrm{O}$ & -0.801 & 1 & & & & & & & & & & & \\
\hline $\mathrm{pH}-\mathrm{KCl}$ & -0.714 & $0.990^{* *}$ & 1 & & & & & & & & & & \\
\hline EA & 0.620 & $-0.959^{*}$ & $-0.976^{*}$ & 1 & & & & & & & & & \\
\hline EC & 0.137 & -0.183 & -0.141 & 0.317 & 1 & & & & & & & & \\
\hline $\mathrm{OM}$ & -0.128 & 0.303 & 0.285 & -0.468 & $-0.976^{*}$ & 1 & & & & & & & \\
\hline $\mathrm{N}$ & -0.901 & $0.962^{*}$ & 0.931 & -0.845 & -0.010 & 0.095 & 1 & & & & & & \\
\hline Avail. P & -0.145 & -0.161 & -0.183 & 0.391 & 0.897 & $-0.953^{*}$ & 0.089 & 1 & & & & & \\
\hline CEC & -0.874 & 0.916 & 0.862 & -0.866 & -0.483 & 0.536 & 0.879 & -0.325 & 1 & & & & \\
\hline $\begin{array}{l}\text { Sum } \\
\text { (Bases) }\end{array}$ & -0.721 & 0.786 & 0.733 & -0.800 & -0.730 & 0.768 & 0.691 & -0.581 & $0.951^{*}$ & 1 & & & \\
\hline Sand & -0.529 & 0.918 & $0.963^{*}$ & -0.937 & 0.024 & 0.156 & 0.841 & -0.130 & 0.695 & 0.549 & 1 & & \\
\hline Silt & 0.217 & -0.710 & -0.797 & 0.771 & -0.243 & 0.037 & -0.619 & 0.043 & -0.386 & -0.236 & -0.931 & 1 & \\
\hline Clay & 0.876 & $-0.971^{*}$ & -0.933 & 0.915 & 0.344 & -0.424 & -0.941 & 0.233 & $-0.984^{*}$ & -0.892 & -0.801 & 0.527 & 1 \\
\hline
\end{tabular}

$*, * *$ Correlation is significant at the 0.05 level and 0.01 level (2-tailed), respectively.

Table 5. Pearson correlation coefficient matrix for total metal concentrations in the soils.

\begin{tabular}{|c|c|c|c|c|c|c|c|c|}
\hline & Zn & $\mathrm{Cu}$ & Mn & $\mathbf{F e}$ & $\mathbf{P b}$ & $\mathbf{N i}$ & $\mathrm{Cr}$ & Cd \\
\hline $\mathrm{Zn}$ & 1 & & & & & & & \\
\hline $\mathrm{Cu}$ & -0.737 & 1 & & & & & & \\
\hline $\mathrm{Mn}$ & 0.407 & 0.312 & 1 & & & & & \\
\hline $\mathrm{Fe}$ & -0.394 & 0.660 & 0.420 & 1 & & & & \\
\hline $\mathrm{Pb}$ & 0.479 & -0.328 & 0.127 & -0.817 & 1 & & & \\
\hline $\mathrm{Ni}$ & 0.238 & 0.474 & $0.984^{*}$ & 0.540 & 0.020 & 1 & & \\
\hline $\mathrm{Cr}$ & -0.051 & 0.661 & 0.859 & 0.807 & -0.326 & 0.930 & 1 & \\
\hline $\mathrm{Cd}$ & -0.414 & 0.804 & 0.562 & $0.960^{*}$ & -0.639 & 0.689 & 0.906 & 1 \\
\hline
\end{tabular}

* Correlation is significant at the 0.05 level (2-tailed).

Table 6. Pearson correlation coefficient matrix for available metal concentrations in the soils.

\begin{tabular}{|c|c|c|c|c|c|c|c|c|}
\hline & $\mathbf{Z n}$ & $\mathbf{C u}$ & Mn & $\mathrm{Fe}$ & $\mathbf{P b}$ & $\mathbf{N i}$ & $\mathrm{Cr}$ & Cd \\
\hline $\mathrm{Zn}$ & 1 & & & & & & & \\
\hline $\mathrm{Cu}$ & 0.903 & 1 & & & & & & \\
\hline Mn & $-0.983^{*}$ & -0.938 & 1 & & & & & \\
\hline $\mathrm{Fe}$ & $0.973^{*}$ & 0.787 & -0.943 & 1 & & & & \\
\hline $\mathrm{Pb}$ & $0.955^{*}$ & $0.989^{*}$ & $-0.978^{*}$ & 0.869 & 1 & & & \\
\hline $\mathrm{Ni}$ & 0.028 & -0.358 & 0.139 & 0.186 & -0.253 & 1 & & \\
\hline $\mathrm{Cr}$ & -0.238 & -0.288 & 0.390 & -0.269 & -0.313 & 0.571 & 1 & \\
\hline $\mathrm{Cd}$ & -0.919 & $-0.993^{* *}$ & $0.963^{*}$ & -0.822 & $-0.993^{* *}$ & 0.361 & 0.389 & 1 \\
\hline
\end{tabular}

$*, * *$ Correlation is significant at the 0.05 level and 0.01 level (2-tailed), respectively. 
was shown to correlate negatively with electrical conductivity $(\mathrm{r}=-0.967)$ and available phosphorus $(\mathrm{r}=-0.953)$ suggesting that soils high in organic matter tend to favour the immobilization of plant nutrients. Total nitrogen and $\mathrm{pH}-\mathrm{H}_{2} \mathrm{O}$ were shown to correlate positively with one another $(r=0.962)$, suggesting that when soil $\mathrm{pH}$ is increased, it increases the mobilization of soil nitrogen, thus rendering it available for plant uptake. Cation exchange capacity correlated positively ( $r$ $=0.951$ ) with the sum of exchangeable bases. Clay was shown to correlate negatively with $\mathrm{pH}-\mathrm{H}_{2} \mathrm{O}(\mathrm{r}=-0.971)$ and $\mathrm{CEC}(\mathrm{r}=$ -0.984). Correlation results showed that relationships existing among soil physicochemical properties interfered with nutrient availability. This conforms to the findings of Tsozue et al. (2016) who showed that plant nutrient availability depends on relationships existing among soil physicochemical properties.

All metals analysed showed a significantly strong positive and negative correlations with one another $(\mathrm{p}<0.05)$ (Table 5 and $6)$. The positive correlation between these metals showed that there was an interaction among these metals in the study area, and on the other hand, they might have similar origins. A strong correlation between two variables or metals may be an occurrence of strong dependence of both variables on the same causal factor probably due to their common derivation from the stores in the basement complex (Osobamiro and Adewuyi, 2015).

Pollution in soil has adverse effect on plant growth (Syed et al., 2012). Pollution in the soils studied could be associated with indiscriminate use of fertilizers, pesticides, insecticides and herbicides, dumping of large quantities of solid waste, deforestation and soil erosion. For instance, $\mathrm{As}, \mathrm{Pb}$ and $\mathrm{Cd}$ present in traces in rock phosphate mineral get transferred to super phosphate fertilizers. Since the metals are not degradable, their accumulation in the soil above their toxic levels due to excessive use of phosphate fertilizers becomes an indestructible poison for crops. Pesticides not only bring toxic effect on human and animals but also decrease the fertility of the soil. Effects of soil pollution include reduced soil fertility, reduced nitrogen fixation, increased erodibility, larger loss of soil and nutrients, reduced crop yield, runs off into rivers that kills fish, may create toxic dusts, may poison children playing in the area and imbalance in soil fauna and flora (Tóth et al., 2016).

Liming influences the transformation and uptake of nutrients and heavy metals by plants through its direct effect on the neutralization of soil acidity and its indirect effect on the physical, chemical and biological characteristics of soils. Liming is increasingly being accepted as an important management tool in reducing the toxicity of heavy metals in soils. In addition to the traditional agricultural lime, a large number of studies have examined the potential value of other liming materials as immobilizing agents in reducing the bioavailability of a range of heavy metals in soils. In this regard Cd contamination of agricultural soils is of particular concern because this metal reaches the food chain through regular use of $\mathrm{Cd}$ containing fertilizer materials, such as single superphosphates. Also it remains mobile even at about neutral $\mathrm{pH}$ (Bolan et al., 2003). Liming has been shown to reduce the amount of $P$ fertilizer required to boost yield in some soils. This reduction in $\mathrm{P}$ requirements results directly from an increased solubilization of soil $\mathrm{P}$ and its subsequent uptake and/or indirectly from an increase in $\mathrm{P}$ uptake due to reduced $\mathrm{Al}$ and $\mathrm{Mn}$ toxicity (Bolan et al., 2003; Hamel et al., 2010). Several reasons have been attributed to the lime-induced immobilization of heavy metals as elucidated by Bolan et al. (2003): increases in negative charge (CEC) in variable charge soils; formation of strongly-bound hydroxy metal species; precipitation of metals as hydroxides; and sequestration due to enhanced microbial activity. However, in soils with low cation exchange capacity, liming may increase the plant availability of heavy metals due to the exchange of lime borne $\mathrm{Ca}$ with the heavy metal ions and subsequent increase in their concentration in soil solution. The net effect of liming on heavy metal transformation in these soils largely depends on the extent of $\mathrm{pH}$ change and $\mathrm{Ca}$ release from the liming material. Lime-induced mobilization of nutrient ions and immobilization of heavy metals are important in sustainable agricultural production and soil environmental protection in the soil studied.

\section{Conclusions}

The main objective of this research work was to assess the quality of agricultural soils of Awing- North West Cameroon by elucidating some physicochemical parameters and toxic heavy metals in the soils. A total of 20 soil samples were collected and analyzed for physicochemical and heavy metals ( $\mathrm{Zn}, \mathrm{Cu}, \mathrm{Mn}, \mathrm{Fe}, \mathrm{Cr}, \mathrm{Ni}, \mathrm{Cd}, \mathrm{Pb}$, and $\mathrm{As}$ ) parameters using standard procedures. The results showed that all the soil samples had low bulk densities, low $\mathrm{pH}$ values ranging from 4.10 - 6.0, low electrical conductivities, average organic matter, low total nitrogen, high $\mathrm{C} / \mathrm{N}$ ratios, low available phosphorus, high CEC values, average sum of exchangeable bases and particle size analysis showed that the soil textural class was loam, clay loam, loam and sand clay loam for Achialum, Meupi, Nepele and Ala'amiti sites respectively. Results of heavy metal analysis showed that the soils were contaminated to different levels by the different heavy metals. Natural origins, fertilizer application and domestic waste were identified as the major sources of heavy metals in the soils. Although heavy metals remain in soil for a very long time, there are some steps that can be taken to reduce the level of risk they pose. For some heavy metals, such as lead, there is little evidence that it is accumulated within crops; the main health hazard is through soil ingestion and inhalation. In general we would need less fertilizer and fewer pesticides if we could all adopt the three R's: Reduce, Reuse, and Recycle. Reduce chemical fertilizer and pesticide use by applying biofertilizers and manures as substitutes. Biological methods of pest control can also reduce the use of pesticides and thereby minimize soil pollution and increasing food safety. Reusing of materials such as glass containers, plastic bags, paper, and cloth at domestic levels rather than being disposed, reducing solid waste pollution. Recycling and recovery of materials is a reasonable solution for reducing soil pollution. This decreases the volume of refuse and helps in the conservation of natural soil resources. To reduce health risks in soils with elevated heavy metal content, food crops should be thoroughly washed to remove as much soil as possible. Outer leaves of leafy greens should be removed and root crops should be peeled to further reduce risk. Future research should aim to focus on the development of methods to quantify lime-enhanced mobilization of nutrient ions and lime-induced immobilization of heavy metals in these soils under field conditions and to explore further the role of liming in remediating contaminated soils.

\section{ACKNOWLEDGEMENTS}

The authors are grateful to the farmers of Awing for providing the necessary information on farming practices in the study area and for permitting us to use their fields for this study. All technicians of the Laboratory of Soil Analysis and Environmental Chemistry (LASAEC), University of Dschang and the 
International Institute of Tropical Agriculture (IITA), Nkolbisson, Yaounde are acknowledged for their commitment in assisting in laboratory analyses.

Conflict of interest: The authors declare that there is no conflict of interest regarding the publication of this article.

Open Access: This is open access article distributed under the terms of the Creative Commons Attribution License, which permits unrestricted use, distribution, and reproduction in any medium, provided the original author(s) and the source are credited.

\section{REFERENCES}

Apongnde, P. (2014). The people of Awing, North West Cameroon. First edition. Pacific Print, Yaounde-Cameroon, pp. 112.

Benton, J.J.J. (2003). Agronomic handbook- management of crops, soils, and their fertility. CRC Press LLC. ISBN: 0-8493-0897-6, USA.

Bitondo, D., Tabi, F.O., Kengmegne, S.S.A., Ngoucheme, M. and Mvondo-Zé, A.D. (2013). Micronutrient concentrations and environmental concerns in an intensively cultivated Typic Dystrandept in Mount Bambouto, Cameroon. Open Journal of Soil Science, 3: 283-288.

Bolan, N.S., Adriano, D.C. and Curtin, D. (2003). Soil acidification and liming interaction with nutrient and heavy metal transformation and bioavailability. Advances in Agronomy, 78: 215-272.

Cheng, S. and Huang, C. (2006). Influence of cadmium on growth of root vegetable and accumulation of cadmium in the edible root. International Journal of Applied Science and Engineering, 4(3): 243-252.

FAO/WHO (2011). Joint FAO/WHO food standards programme codex committee on contaminants in foods. Working document for information and use in discussions related to contaminants and toxins in the Gsctff. Fifth Session. Hague, The Netherlands. pp. 90.

FAO (2006). Guidelines for soil profile description. Food and Agriculture Organization of the United Nations, $4^{\text {th }}$ edition. ISBN: 92-5-105521-1, pp.97.

Hamel, S., Heckman, J. and Murphy, S. (2010). Lead contaminated soil: minimizing health risks. Fact sheet FS336. Rutgers, the State University of New Jersey, New Jersey Agricultural Experiment Station. Retrieved from http://njaes.rutgers.edu/ pubs/publication.asp?pid=FS336.

Horneck, D.A., Sullivan, D.M., Owen, J.S. and Hart, J.M. (2011). Soil test interpretation guide. EC 1478, Oregon State University Extension Service, Oregon State University, Corvallis.

NACDA (2010). Ndong Awing Cultural and Development Association (NACDA) archives.

Njoyim, E.B.T., Mvondo-Zé, A.D., Mofor, N.A. and Onana, A.A. (2016a). Phosphorus adsorption isotherms in relation to soil characteristics of some selected volcanic affected soils of Foumbot in the West Region of Cameroon. International Journal of Soil Science, 11: 19-28.

Njoyim, E.B.T., Mvondo-Zé, A.D., Ghogomu, J.N. and Mofor, N.A. (2016b). Evaluation of phosphorus sorption characteristics of soils from the Bambouto sequence (West Cameroon). Interna- tional Journal of Biological Chemical Sciences, 10(2): 860-874.

Njoyim, E.B.T, Donfack, A., Mofor, N.A. and Tchiaze, F.G. (2016c). Phytoextraction of cadmium by beans and sweet potatoes from soils. International Journal of Research and Reviews in Applied Sciences, 28 (2): 65-70.

Oluyemi, E.A., Feuyit, G., Oyekunle, J.A.O. and Ogunfowokan, A.O. (2008). Seasonal variations in heavy metal concentrations in soil and some selected crops at a landfill in Nigeria. African Journal of Environmental Science and Technology, 2 (5): 089096.

Osobamiro, M.T. and Adewuyi, G.O. (2015). Levels of heavy metals in the soil: effects of season, agronomic practice and soil geology. Journal of Agricultural Chemistry and Environment, 4:109-117.

Ruqia, N., Muslim, K., Muhammad, M., Hameed, U.R., Naveed, U.R., Surrya, S., Nosheen, A., Muhammad, S., Mohib, U., Muhammad, R. and Zeenat, S. (2015). Accumulation of heavy metals $(\mathrm{Ni}, \mathrm{Cu}, \mathrm{Cd}, \mathrm{Cr}, \mathrm{Pb}, \mathrm{Zn}, \mathrm{Fe})$ in the soil, water and plants and analysis of physico-chemical parameters of soil and water collected from Tanda Dam Kohat. Journal of Pharmaceutical Science \& Research, 7(3): 89-97.

Schroeder, B., Wood, A. and Panitz, J. (2007). Accelerating the adoption of best practice nutrient management: Burdekin district. BSES Limited, Brisbane.

Silva, J. and Uchida, R.S. (2000). Plant Nutrient Management in Hawaii's Soils: Approaches for Tropical and Subtropical Agriculture. College of Tropical Agriculture and Human Resources, University of Hawaii at Manoa, Honolulu, USA.

Spargo, J., Allen, T. and Kariuki, S. (2013). Interpreting your soil test results. The College of Natural Sciences, Soil and Plant Tissue Testing Laboratory, USDA, Amherst, MA.

Syed, H.R., Dilara, K., Tanveer, M.A., Mohammad, S.I., Mohammad, A.A. and Mohammad, A.A. (2012). Assessment of heavy metal contamination of agricultural soil around Dhaka Export Processing Zone (DEPZ), Bangladesh: Implication of Seasonal Variation and Indices. Applied Sciences, 2: 584-601.

Tematio, P., Kengni, L., Bitom, D., Hodson, M., Fopoussi, J.C., Leumbe, O., Mpakam, H.G. and Tsozué, D. (2004). Soils and their distribution on Bambouto volcanic mountain, West Cameroon highland, Central Africa. Journal of African Earth Sciences, 39: 447-457.

Tóth, G., Hermann, T., Da Silva, M.R. and Montanarella, L. (2016). Heavy metals in agricultural soils of the European Union with implications for food safety. Environment International, 88: 299 -309 .

Tsozué, D., Tematio, P. and Tamfuh, P.A. (2016). Relationship between soil characteristics and fertility implications in two typical dystrandept soils of the Cameroon Western Highland. International Journal of Soil Science, 11: 36-48.

Vodyanitskii, Y.N. (2016). Standards for the contents of heavy metals in soils of some states, Annals of Agrarian Science, 14: 257-263.

Yaser, H. and Rahim, D.T. (2013). Comparison of phosphorus adsorption isotherms in soil and its relation to soil properties. International Journal of Agricultural Research Reviews, 3: 163-171.

Yerima, P.K.B. and Van Ranst, E. (2005). Introduction to soils science: Soils of the tropics. $1^{\text {st }}$ Edition. ISBN 1-4120-5853-8. Flemish Interuniversity Council. 